\title{
PROPOSTA DE MERCADO PÚBLICO ATRAVÉS DOS CONCEITOS DA PERMACULTURA URBANA
}

\author{
PROPUESTA DE MERCADO PÚBLICO A TRAVÉS DE LOS CONCEPTOS DE LA PERMACULTURA \\ URBANA
}

PUBLIC MARKET PROPOSAL THROUGH THE CONCEPTS OF URBAN PERMACULTURE

\section{SANTOS, ÍSIS PORTOLAN}

Arquiteta e Urbanista, Doutora em engenharia Civil. Professora da Universidade Federal de Santa Maria, isis.santos@ufsm.br.

\section{MAYER, LICIA QUOOS}

Arquiteta e Urbanista pela Universidade Federal de Santa Maria, liciaquoosm@gmail.com.

\section{RESUMO}

0 presente trabalho trata de uma pesquisa e de um projeto arquitetônico/paisagístico realizado para o Trabalho Final de Graduação do Curso de Arquitetura $e$ Urbanismo da Universidade Federal de Santa Maria (UFSM/RS). A metodologia do projeto iniciou com a pesquisa e posterior seleção de diretrizes, zoneamentos, estudos de fluxos e de volumetria até a proposição arquitetônica e paisagística na forma de um anteprojeto. A pesquisa contemplou o levantamento histórico, físico, cultural e social do terreno e dos prováveis usuários. A revisão bibliográfica analisou o histórico dos mercados públicos, a permacultura, o paisagismo produtivo e as soluções sustentáveis na construção civil. 0 levantamento de dados ocorreu através da aplicação de questionário para usuários e comerciantes locais, e também da seleção e análise dos aspectos físico-sociais da cidade, do bairro e do entorno próximo ao sítio escolhido. Estes serviram para a elaboração do programa de necessidades, vinculados com as premissas indicadas no referencial teórico. A partir de então, foram inseridos itens da permacultura em diferentes aspectos do projeto, tais como a: recuperação de áreas de preservação, paisagismo produtivo urbano, utilização de estruturas e materiais naturais, apresentação de infraestruturas alternativas como solução para saneamento básico, tratamentos dos efluentes nos espaços urbanos e destinação adequada de resíduos sólidos. Assim, foi possível desenvolver uma proposta arquitetônica e paisagística com premissas da permacultura que se apresentam como soluções pertinentes para espaços públicos, em especifico para um Mercado Público em um bairro de Santa Maria/RS.

PALAVRAS-CHAVE: espaço público; mercado público; permacultura; permacultura urbana; sustentabilidade.

\section{RESUMEN}

El presente trabajo aborda la investigación y el diseño arquitectónico / paisajistico realizado para el Trabajo Final de Graduación del Curso de Arquitectura y Urbanismo de la Universidad Federal de Santa María (UFSM / RS). La metodología del proyecto se inició con la investigación y posterior selección de lineamientos, estudios de zonificación, estudios de flujos y volumetría hasta la propuesta arquitectónica y paisajistica en forma de anteproyecto. La investigación incluyó la historia de los mercados públicos, la permacultura, el paisajismo productivo y las soluciones sostenibles en la construcción civil. La recolección de datos se llevó a cabo mediante la aplicación de un cuestionario para usuarios y comerciantes locales, y también la selección y análisis de los aspectos físicos y sociales de la ciudad, el barrio y el entorno cercano al sitio elegido. Estos se utilizaron para elaborar el programa de necesidades, vinculado a las premisas indicadas en el marco teórico. Desde entonces, los elementos de la permacultura se han insertado en diferentes aspectos del proyecto, tales como: recuperación de áreas de preservación, paisajismo productivo urbano, uso de estructuras y materiales naturales, presentación de infraestructura alternativa como solución para el saneamiento básico, tratamiento de efluentes en espacios urbanos y adecuada disposición de residuos sólidos. Así, fue posible desarrollar la propuesta arquitectónica y paisajistica con premisas de permacultura que se presentan como soluciones relevantes para los espacios públicos, especificamente para un Mercado Público en un barrio de Santa Maria/RS.

PALABRAS CLAVE: espacio público; mercado público; permacultura; permacultura urbana; sostenibilidad.

\section{ABSTRACT}

The present work describes the research and architectural/landscape project developed as a Final Graduation Project for the achievement of the Architecture and Urbanism Degree at the Federal University of Santa Maria (UFSM/RS). The Project methodólogy started with research and subsequent selection of guidelines, zoning, flow and volumetry studies up to the architectural and landscape proposal in the form of a preliminary project. Plubic market historical, permaculture, productive landscape and sustainable constructions were analyzed in references. Data collection focused on land site and it relation with the city and the neightborhood using maps and information about population. The local data collection that took place through the application of a questionnaire for users and local traders and the selection and analysis of physical and social aspects of the city, the neighborhood and the surroudings near the chosen site. These were used to prepare the needs program, linked to the premises indicated in the theoretical frameword. Permaculture was used to define several aspects in archtecture and landscape design, especially in zones and site configuration degraded áreas recovery, productive landscape. Wood and other local materials, sanitationm effluent treatment, and solid waste destination Thus, it was possible to develop na archtectural and landscaping proposal based on permaculture premises, which show themselves as relevant and sustainable solutions for public spaces, specifically for a Public Market in a neighborhood of Santa Maria/RS 


\section{INTRODUÇÃO}

O presente artigo apresenta o desenvolvimento do projeto intitulado Proposta de Mercado Público através da permacultura urbana para Santa Maria/RS. O objetivo do trabalho foi fundamentar e disseminar informações sobre a relação entre a permacultura e o projeto paisagístico e arquitetônico de equipamentos públicos.

Camobi, o bairro escolhido, é uma das áreas de maior desenvolvimento da cidade. O município situa-se há cerca de $290 \mathrm{~km}$ da capital, Porto Alegre. Em Camobi, também se localiza a Universidade Federal de Santa Maria e a Base Aérea Ala 4, dois pontos fundamentais que nortearam o crescimento da região. Na última década, houve um crescimento acelerado no bairro devido à ampliação da universidade, e consequentemente, de novas moradias de seus estudantes e servidores. $\mathrm{O}$ crescimento do bairro tem se dado de forma desordenada, mas seguindo o entorno da RS-287 e da RS-509. Isto ocasionou o comprometimento de várias áreas de preservação e córregos existentes, além da formação de vazios urbanos. Também salientam-se ações de pavimentação e arruamentos com valorização dos automóveis em detrimento dos pedestres ou ciclistas

No início de sua história, o bairro tinha caráter rural, característica que ainda permanece em determinados locais, com produção de horticulturas, e na presença de feiras itinerantes de pequenos agricultores. Estas feiras estão configuradas com bancas de lonas, vulneráveis às intempéries e não há um local adequado com acesso e infraestrutura para as mesmas. Outra questão importante no bairro é a falta de locais para estar, lazer e convivência, principalmente após o aumento do número de moradores.

Devido à urbanização desordenada e ao estilo de vida "insustentável" da sociedade moderna, novas construções sustentáveis, com utilização de paisagismo produtivo, trariam consigo a possibilidade de propiciar espaços mais saudáveis, incluindo áreas de lazer e estar para a população. Assim, este trabalho considera esta premissa na proposta de um Mercado Público, a partir da Permacultura. Este espaço ainda criaria local para capacitação produtores locais e disseminação de conhecimentos para toda a comunidade. Os princípios da permacultura e agroecologia foram elementos fundamentais para indicar soluções inovadoras na ocupação dos vazios urbanos de maneira resiliente e com valorização dos usuários.

\section{DESENVOLVIMENTO}

Os mercados públicos surgiram na antiguidade como forma de intercâmbio de produtos. Devido ao fato de poderem dialogar com outras formas comerciais, eles resistem até os dias atuais. No decorrer do tempo estes locais foram consolidando-se como espaço econômico, político e social dentro das cidades, ressaltando sua importância como um espaço democrático e acessível. As diversas formas de interação socioculturais podem ocorrer em um mercado público, o que os diferencia dos supermercados que surgiram no século XX, que globalizaram as relações e distanciaram os consumidores dos produtores.

Quando inserido em um tecido urbano, o Mercado Público pode ser um elemento de articulação social dentro de um bairro, onde diversas funções podem ser exercidas, além de suas características primárias, de forma que este equipamento pode tornar-se um potencializador de coletividade e urbanidade.

O bairro Camobi foi o escolhido, principalmente para resgatar seu senso de coletividade, em que o Mercado poderia funcionar também como espaço de lazer e conhecimento à sua comunidade. Além disso, a proposição busca a proteção de áreas de preservação vegetal através da utilização de vazios urbanos existentes no decorrer da RS-509, transformando-os em forma de parques lineares de conexão entre as vias, valorizando os pedestres.

A permacultura prevê o cuidado do essencial, das relações, das pessoas, da natureza, da alimentação e dos princípios éticos e cuidados pela cidade, sendo assim, uma possibilidade de solução para espaços urbanos, principalmente para bairros. Esta traz um olhar sistêmico para o todo, combatendo a maneira como as cidades extraem os recursos naturais, sem uso racional da água, sem eficiência na obtenção e consumo de alimentos e energia e nem destino adequado para os resíduos gerados.

O bairro apresenta em diversos lotes a produção de hortaliças para consumo próprio, além de estar próximo de uma região rural com predomínio de agricultura familiar, o que justifica a implantação de um espaço para disseminação de informações e capacitação dos produtores. Assim, além do local fixo e adequado para comercialização de produtos, o mercado também apresentará uma área de propícia para esta troca de conhecimentos.

Dessa forma, o tema proposto prevê o Mercado Público de Camobi, com valorização da sociedade e da natureza, aproximando-as e promovendo a troca de valores urbanos e socioculturais, configurando este 
projeto como catalisador para tais intenções e inserindo-se no tecido urbano, reconhecendo seu entorno e sua história.

\section{Metodologia}

Este trabalho foi desenvolvido através de uma metodologia dividida em três etapas: revisão teórica, levantamento de dados e síntese propositiva.

A revisão teórica foi feita a partir da revisão bibliográfica dos temas que nortearam o projeto, como Mercado Público e Permacultura. Estes aspectos foram revisados através de bibliografias específicas ao tema e também com estudos de caso de obras arquitetônicas exemplares de mercados e projetos com uso da permacultura. Esta atividade foi importante para compreender a conceituação teórica dos temas e também a materialidade e ocupação das obras arquitetônicas.

A etapa de levantamento de dados foi feita com dois focos, análise do sítio e análise das necessidades humanas. A análise do sítio foi feita a partir da revisão histórica do crescimento do bairro, informações topográficas e climáticas, análise de infraestrutura urbana meio de dados obtidos pelo IBGE (2020) e dados locais (Santa Maria, 2019), artigos e pesquisa in loco. O levantamento sobre as necessidades humanas foi feito a partir da avaliação das feiras existentes próximas ao local, espacialização das mesmas em mapa e questionários com os produtores e usuários. Dois questionários foram criados, 46 pessoas foram entrevistadas. O primeiro foi estruturado para os produtores e comerciantes, com 13 perguntas. O segundo foi aplicado para 26 consumidores das feiras, com 16 perguntas. Essa etapa resultou na planta baixa do terreno, análise das relações com o entorno e, também, no programa de necessidades.

A terceira etapa compreendeu a elaboração do anteprojeto arquitetônico e paisagístico, respeitando as necessidades e limitações obtidas na etapa anterior. O anteprojeto foi iniciado pela elaboração do conceito norteador da proposta com base no referencial teórico, buscando as representações bibliográficas, formais e construtivas do mesmo. Em seguida, foram elaboradas as diretrizes em três escalas e iniciada a etapa de partido com zoneamento, volumetria e implantação. Esta etapa foi submetida a uma banca de avaliação onde foram feitas algumas sugestões. A partir disso, foi iniciada a etapa de anteprojeto que contemplou as definições de planta baixa, cortes, fachadas e estudos volumétricos. O projeto foi finalizado com elaboração dos projetos complementares e maquetes físicas e eletrônicas.

\section{Histórico e referências dos Mercados Públicos}

Os mercados emergiram com o surgimento e crescimento das cidades, ampliando-se pela facilidade de deslocamento entre elas. Conforme Barbosa (2016, p. 22), "era o lugar onde diferentes sociais podiam conviver em harmonia". Desde seu início, os mercados marcaram civilizações por serem espaços urbanos com elevado potencial sóciocultural. Ao longo da história, desde feiras livres em praças e ruas até formas mais complexas, os mercados atuaram como catalisador para o desenvolvimento das cidades ou modificação das mesmas.

Além da revisão teórica, foram analisadas referências arquitetônicas, entre elas: O Espaço $S$, um local cultural na cidade de Dong Van, Vietnã. O parque urbano Hi-tech em Xangai, China. O Mercat de Santa Caterina em Barcelona, Espanha; O jardim botânico Van Dusen no Canadá. Também foi feito um estudo de caso, este realizado no Mercado Público de Porto Alegre-RS, com levantamento de dados in loco.

\section{A Permacultura Urbana}

Em 1978, os ecologistas australianos Bill Mollison e David Holmgren desenvolveram o conceito e sistema de permacultura. Para Bill Mollison (1998, p. 13) a "permacultura é a filosofia de trabalhar com e não contra a natureza, depois de uma observação atenta e transferível para o cotidiano, em oposto ao trabalho descuidado". Já Holmgren (2002, p. 33), define o termo como "aquelas paisagens conscientemente projetadas que simulam ou imitam os padrões e as relações observadas nos ecossistemas naturais."

Segundo Dias (2007), a urbanização acelerada e caótica ameaça a qualidade de vida da população, que sofre consequentemente, com a poluição do ar, água e solo, falta de saneamento, problemas de trânsito, produção excessiva de lixo, entre outros. A falta de infraestrutura adequada, carência de reflexão, de pensamento crítico e o individualismo, não permitem que, nos centros urbanos, as necessidades básicas sejam supridas sem causar sérios impactos ambientais. 
Nesse contexto, a Permacultura surge como uma alternativa promissora para o desenvolvimento de cenários, cidades e/ou espaços sustentáveis e resilientes. A proposta básica da mesma determina que é necessário mudar o estilo de vida para que o mundo possa transformar-se também, assim como agir localmente, pensando globalmente. A permacultura trabalha com princípios que nos permite pôr em prática um sistema humano completo, eficiente e sustentável. De acordo com Bill Mollison (1998), a mesma consiste no planejamento e execução de sociedades sustentáveis, que unem técnicas ancestrais à tecnologia atual das áreas de engenharia, arquitetura e urbanismo, ciências agrárias, ciências sociais, todas conectadas sob a ótica da ecologia.

Segundo Rosemary Morrow (2010 apud CJ, 2016), os principais aspectos da Permacultura podem ser resumidos da seguinte maneira: sistema de criação de comunidades sustentáveis que integra ecologia e design, sendo uma síntese do conhecimento tradicional e da ciência moderna, aplicável às áreas urbanas e rurais. Além disso, estimula a nos tornarmos parte consciente de soluções, frente aos inúmeros problemas que enfrentamos nos assentamentos humanos e áreas de produção.

Na permacultura o conceito de zonas é fundamental; Estas estão organizadas de acordo com a área de terra, com base no tempo que despendemos em cada uma delas, e a partir de suas funções (Figura 1). O objetivo é zonear de uma maneira sintrópica, ou seja, uma maneira que contribui para o equilíbrio e o desenvolvimento organizacional, otimizando o tempo e gasto de energia. Na sua forma mais simples, as zonas são círculos concêntricos, porém as mesmas podem assumir diversas formas.

Figura 1: Esquema ilustrativo das zonas da permacultura.

\begin{tabular}{l}
$\begin{array}{l}\text { Zona zero: Centro da atividade, projetada para } \\
\text { a conservação de energia e para ajustar-se às } \\
\text { necessidades dos seus ocupantes. }\end{array}$ \\
$\begin{array}{l}\text { Zona um: É a denominada área do quintal; esta } \\
\text { requer mais tempo e energia para manter e } \\
\text { normalmente se situa de } 15 \text { a } 20 \text { metros da } \\
\text { edificação. Projeta-se essa zona em áreas que } \\
\text { são acessadas várias vezes por dia, nela são } \\
\text { plantados os vegetais anuais e ervas } \\
\text { aromáticas. }\end{array}$ \\
\hline $\begin{array}{l}\text { Zona dois: Nela são cultivados legumes } \\
\text { maiores, anuais e perenes, que não necessitam } \\
\text { de atenção diária, e também os arbustos } \\
\text { maiores, árvores frutíferas de pequeno porte, } \\
\text { lagos, área maior de compostagem. }\end{array}$ \\
$\begin{array}{l}\text { Zona três: Contêm pomares não podados, as } \\
\text { plantas incluem quebra-ventos, arvoredos e } \\
\text { árvores maiores. Além de quaisquer elementos } \\
\text { que sejam colhidos anual ou mensalmente. }\end{array}$ \\
$\begin{array}{l}\text { Zona quatro: Geralmente presentes em áreas } \\
\text { maiores. Incluem árvores de grande porte, } \\
\text { árvores de lenha e colheitas selvagens, de } \\
\text { visitas mensais ou anuais. }\end{array}$ \\
\hline $\begin{array}{l}\text { Zona cinco: Área selvagem, local de união } \\
\text { com a natureza e observação dos seus } \\
\text { modelos e padrões. Local em que não há } \\
\text { intervenção, de vegetação maciça e de } \\
\text { preservação. }\end{array}$
\end{tabular}

Fonte: Adaptado pelas autoras a partir de Mollison (1998) e Dias (2019).

\section{Área de Intervenção}

Santa Maria está localizada na porção central do Rio Grande do Sul (Figura 2). Possui uma estimativa de 282.123 habitantes (IBGE, 2019) e é considerada uma cidade média, sendo a 5ํㅗㄹ mais populosa do Estado. O bairro Camobi é o maior em área $\left(20.5186 \mathrm{~km}^{2}\right.$ o que equivale a $16,84 \%$ do distrito sede) e em população absoluta de (21.822 habitantes, no ano de 2010) (IBGE, 2014 apud SANTA MARIA, 2019). O mesmo é composto pela região administrativa leste. 


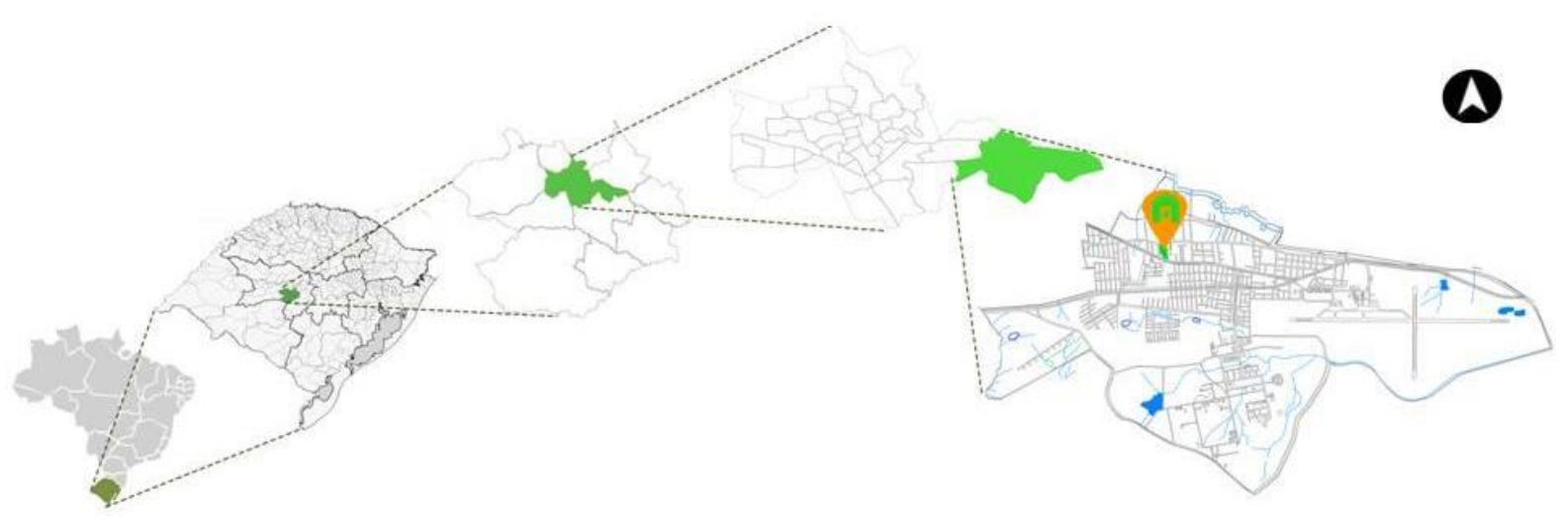

Fonte: Elaborado pelas autoras (2019).

A escolha do terreno se deu devido ao contexto histórico do bairro, de uma região residencial próxima à região rural produtiva. O terreno está situado em uma área de fácil acesso, tanto pelo centro da cidade ao bairro (está entre a UFSM e o bairro Centro), ou pelo acesso às cidades e distritos vizinhos. Possui testada norte voltada para a RS-509, importante via arterial da cidade. No lote, há a presença de um córrego e uma grande área de preservação (Figura 3). Essa escolha foi no sentido de tentar contradizer o crescimento acelerado do bairro, com considerável aterramento de córregos e desmatamento das áreas de preservação. A escolha por este terreno foi então justamente para ressaltar a necessidade de recuperação de aspectos naturais junto aos equipamentos arquitetônicos, podendo servir como elemento de disseminação destas diretrizes projetuais.

Figura 3: Visual do terreno desde a Faixa Velha, à esquerda APP's e ao fundo os morros e visual a partir do centro do lote, respectivamente.

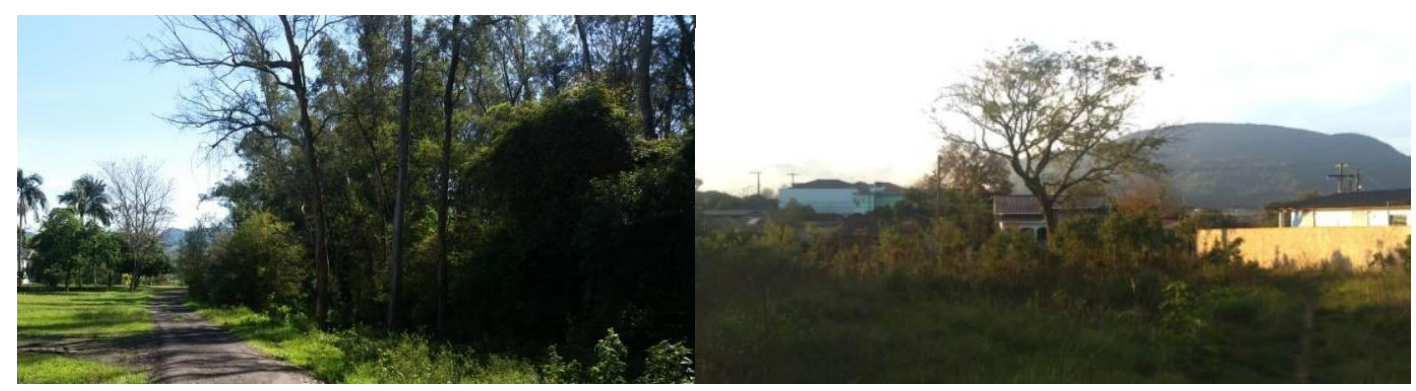

Fonte: Autoras (2019).

Além desses aspectos, observaram-se também as questões naturais do entorno, como as visuais dos morros ao norte, oeste e leste e a falta de praças de bairro e ambientes de estar e lazer para a população. Além disso, foi considerado que o lote já serve como caminho informal pelos pedestres, que o usam como atalho devido à longa dimensão da quadra, delimitada pelas vias consolidadas.

\section{Análise Social}

Os principais dados coletados no questionário aplicado aos produtores locais mostraram que a totalidade dos entrevistados reside em distritos próximos à Cidade e ao bairro Camobi. Cerca de $70 \%$ destes gostariam de expor seus produtos em um espaço adequado para feiras. A metade deles conhece ou já inseriu em seu sítio ações de permacultura ou produção sustentável e 100\% dos entrevistados da feira orgânica conheciam ou já aplicaram métodos sustentáveis de produção. Além disso, 90\% dos entrevistados mostraram interesse em aprender ou aprofundar conhecimento sobre a permacultura. Ainda, 100\% acreditam que a consolidação e fortalecimento de um comércio sustentável influenciam de forma positiva no cotidiano deles, dos consumidores e do meio ambiente.

No segundo questionário, aplicado aos consumidores, 46,15\% responderam que residem em Camobi, e 50\% destes afirmaram que usam parques ou o campus da UFSM como ambiente de estar. Cerca de $81,81 \%$ do total não utilizam de locais de lazer no bairro e $88,46 \%$ deslocam-se para o centro da cidade para usufruir 
destes. Isto pode significar que, mesmo com uma grande representatividade de moradores do bairro, estes ainda necessitam locomover-se para o centro para realizar atividades de lazer.

Relativo à circulação, segurança e arborização no bairro, a maioria dos entrevistados afirma que a circulação para pedestres é precária (82\%) e insegura (73\%). Esses dados corroboram a análise realizada sobre a mobilidade e o sistema viário do bairro que aponta a prioridade dos automóveis. No que concerne à arborização do bairro, $58 \%$ das pessoas consideram a mesma precária.

A terceira parte buscou questionar os consumidores se eles utilizariam um espaço destinado para a venda de produtos provindos da agricultura familiar e pequenos comerciantes, e $96,15 \%$ confirmaram. Sobre praças e parques destinados para estar e circulação de pedestres, 92,30\% responderam que, sim, também o utilizariam. Estes dados confirmaram a deficiência e necessidade de espaços para tais usos, definidos pela proposta, no bairro.

As últimas perguntas foram referentes à sustentabilidade. Perguntados se a consolidação de um comércio sustentável influencia de forma positiva no cotidiano e no meio ambiente, 92,30\% confirmaram. As outras perguntas implicaram no conhecimento sobre a permacultura e outros métodos e princípios alternativos, em que $58 \%$ responderam que já conheciam. E se estes estariam dispostos a aprender sobre tais assuntos em oficinas ministradas no local, $94 \%$ afirmaram que sim. Através desta análise, foi possível observar que este é um assunto ainda desconhecido, porém, com grande potencial para ser introduzido no cotidiano das pessoas e como solução de design e arquitetura, acarretando em benefícios para a população e para o meio ambiente.

\section{Conceito da proposta}

O conceito desta proposta arquitetônica parte da permacultura, que é o desenho consciente de sistemas produtivos que têm diversidade, estabilidade e a resiliência dos ecossistemas naturais como mostra a figura 4. Esses padrões naturais foram estudados pelo matemático italiano "Fibonacci", que transcreveu uma das sequências mais instigantes da matemática, conhecida como sequência de Fibonacci. Esta compreende uma série de números infinitos, onde cada número é a soma dos dois anteriores, os primeiros números são o $0 \mathrm{e}$ 1 , seguido de, 2,3,5,8,13,21,34,55 e assim por diante. O resultado da divisão de dois termos consecutivos da sucessão, como por exemplo, $(34: 21=1,619)(89: 55=1,618)$, permite obter sucessivas aproximações chamadas de PHI (FERRER, 2005).

Figura 4: Imagem desenvolvida pela autora explorando os conceitos dos padrões naturais, do retângulo áureo e das diretrizes da permacultura e do projeto.

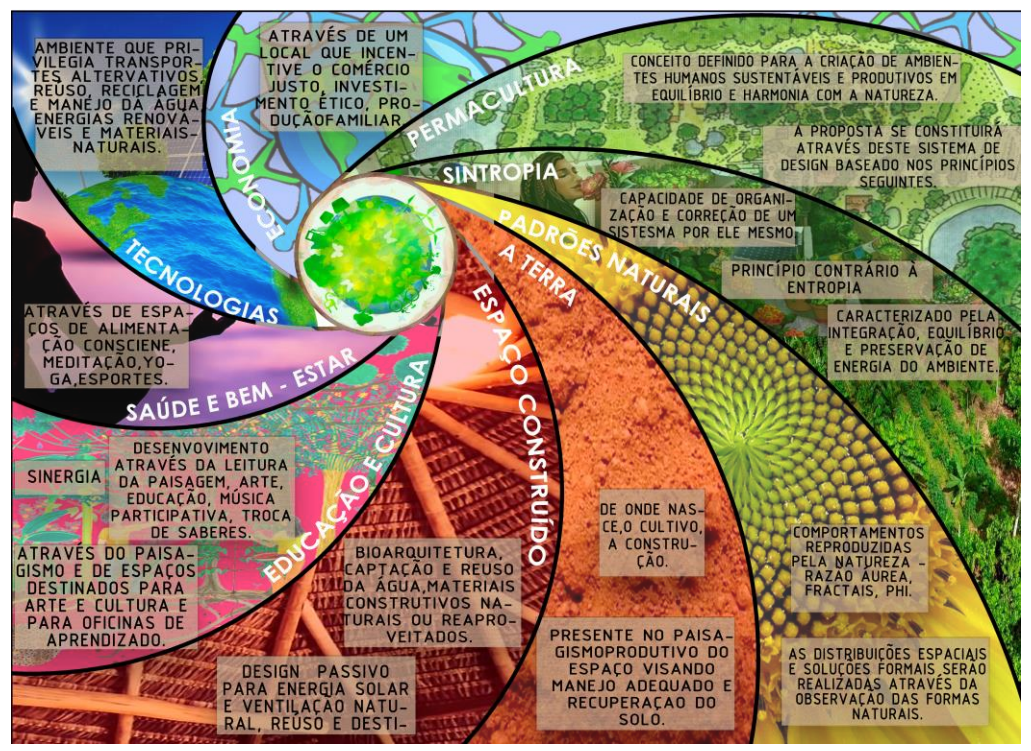

Fonte: Elaborado pelas autoras (2019).

Essa sequência aparece na natureza como padrões, no comportamento da refração da luz, na harmonia musical, dos átomos, do crescimento das plantas, nas espirais das galáxias, nas ondas dos oceanos, furacões, entre outros (FERRER, 2005). Arquitetos famosos, como Le Corbusier, também adotaram a razão áurea como parâmetro de construção de suas obras, utilizada com a finalidade de salientar a harmonia e a beleza. 
Assim, a partir da análise do conceito de permacultura, e seus princípios norteadores que são baseados na observação da natureza e seus padrões, o conceito adotado para nortear as decisões projetuais de composição formal foi o padrão do retângulo áureo.

\section{Diretrizes}

As diretrizes foram determinadas em três escalas: Macro, Meso e Micro. A escala macro contempla a cidade de Santa Maria para esta foram propostas apenas diretrizes. No estudo da escala meso, que contempla o bairro Camobi e entorno ao lote, foram utilizadas as mesmas diretrizes da escala Macro e também realizado o zoneamento das proposições (Figura 5). Por último, na escala micro, foram desenvolvidas diretrizes alinhadas com o programa de necessidades e elaborado o anteprojeto paisagístico e arquitetônico.

Figura 5: Mapa de ações e zoneamentos proposto para o bairro Camobi.

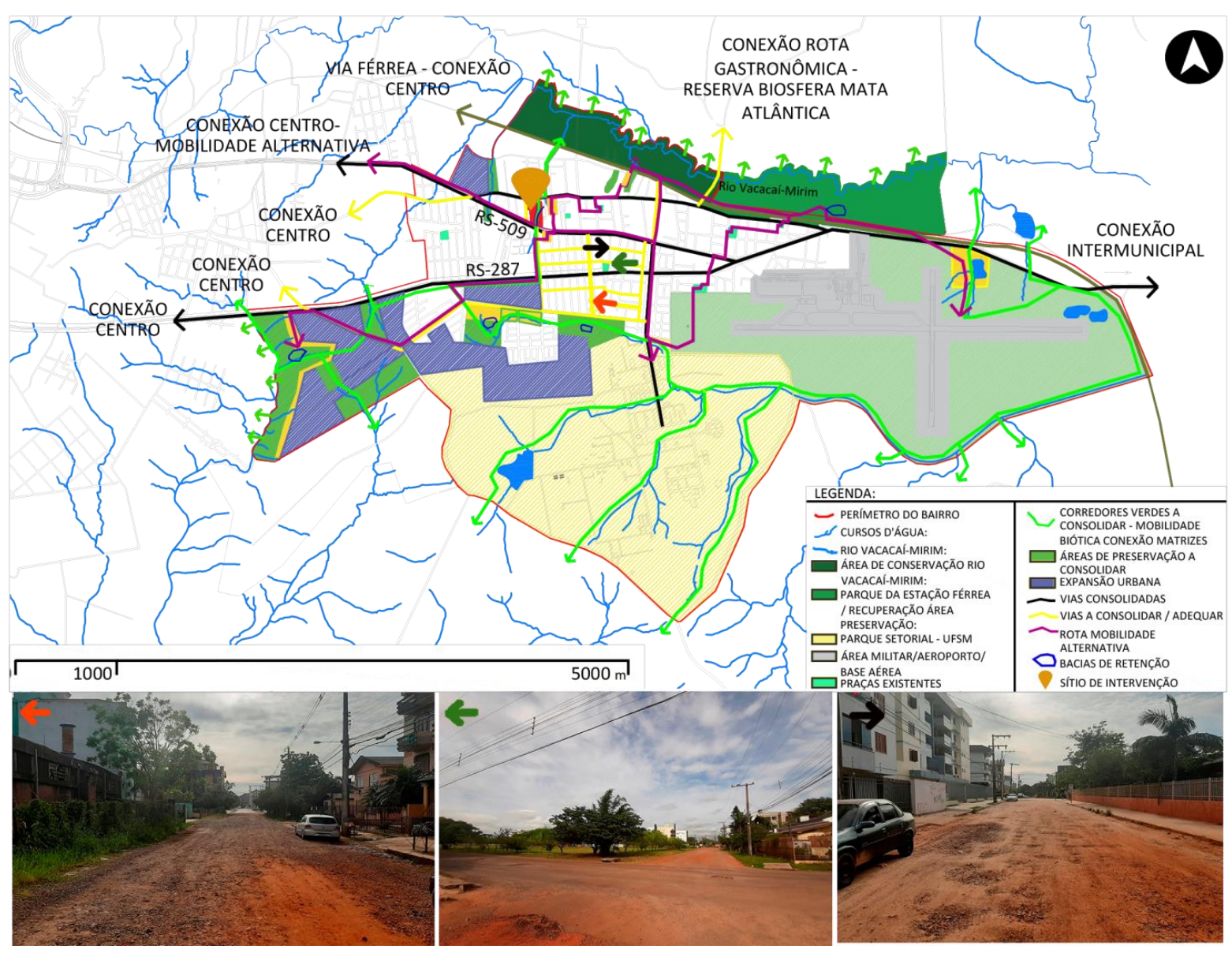

Fonte: Elaborado pelas autoras (2019).

Para as escalas macro e meso, as diretrizes foram: implantar hortas em vazios urbanos, praças e parques; promover a locomoção por meios alternativos não motores de transporte; valorizar a "pedestrinação" através do melhoramento das condições de travessias e tornando-as inclusivas; proposição de iluminação pública; áreas com a presença de córregos e vegetação de preservação permanente devem ser recuperadas e/ou conservados visando à recuperação de biomas naturais e atraindo, assim, a fauna local visando recuperar o equilíbrio ecológico; conexão de pontos através de corredores verdes e destes para com a área de matriz ecológica existente (morros distintos na cidade e no bairro o morro do Elefante e área de conservação do Rio Vacacaí Mirim ao norte); facilitação da mobilidade biótica e valorização das visuais e ecoturismo na área de matriz e entorno; estimular a vitalidade urbana através da inserção de equipamentos públicos e paisagismo produtivo; proposição de sistemas de tratamento de efluentes alternativos como o círculo de bananeiras e tanques de evapotranspiração, para suprir a falta de sistemas de recolhimento de águas cinzas e negras no bairro; inserir infraestruturas verdes e bacias de armazenamento de água para auxiliar na drenagem 
essencialmente em áreas suscetíveis a alagamentos; conectar a área do lote a outras áreas de preservação do entorno, bem como da cidade.

Para a escala micro, as diretrizes contempladas foram: inserção de um espaço que incentive a integração social, com facilitação de cursos, oficinas e manutenção do paisagismo proposto; edificação com escala condizente com seu entorno urbano e que permita a conexão com a escala humana; criação de percursos fluidos, através de soluções baseadas na observação dos padrões naturais; facilitar a locomoção de pedestres; privilegiar a mobilidade através de meios alternativos de transporte; recuperação do córrego e da área de preservação existente no local; manter a topografia existente e valorizar as visuais dos morros; conectar espaços internos e externos do lote através da cultura e do comércio itinerante; implantar sistemas alternativos de tratamentos dos efluentes e dejetos produzidos no local, como tanques de evapotranspiração para as águas cinzas e negras, assim como a compostagem e reciclagem para resíduos sólidos.

\section{O projeto (Escala Micro)}

Para o desenvolvimento do projeto, foram utilizadas três malhas norteadoras (Figura 6). A primeira através de uma malha radial que organiza a malha estrutural da edificação proposta. A segunda através de arcos e raios concêntricos partindo da centralidade da edificação. E uma terceira malha com a criação de uma nova centralidade na área de preservação do local, com arcos e raios que serviram de base aos traçados do paisagismo.

A solução final do projeto paisagístico (Figura 7) apresenta a distribuição das zonas baseadas nas premissas da permacultura e de acordo com estas, a localização dos espaços definidos pelo programa de necessidades.

Na Figura 8, é possível perceber as relações dos fluxos no local. A consolidação da nova via proposta (seta preta), sendo esta uma via compartilhada entre diversos modais e também pelos pedestres. Através da nova via ocorre 0 acesso ao lote para os comerciantes e demais serviços de infraestrutura (setas vermelhas). $O$ fluxo dos usuários, consumidores ou pessoas em busca de estar e lazer, distribui-se pelo lote com diversas possibilidades de acessos e percursos (seta em roxo). O meio de transporte alternativo está configurado por meio de uma ciclovia que percorre o lote, e que se insere também em meio a área de preservação (seta laranja). O fluxo dos resíduos do local ocorre no setor oeste do lote onde estão localizadas as áreas de infraestrutura, compostagem e ou destinação para outro local mais adequado (setas marrons).

Figura 6: Malhas e eixos norteadores para a solução de implantação do proposto projeto tendo como um centro a própria edificação e outra centralidade na área de preservação presente.
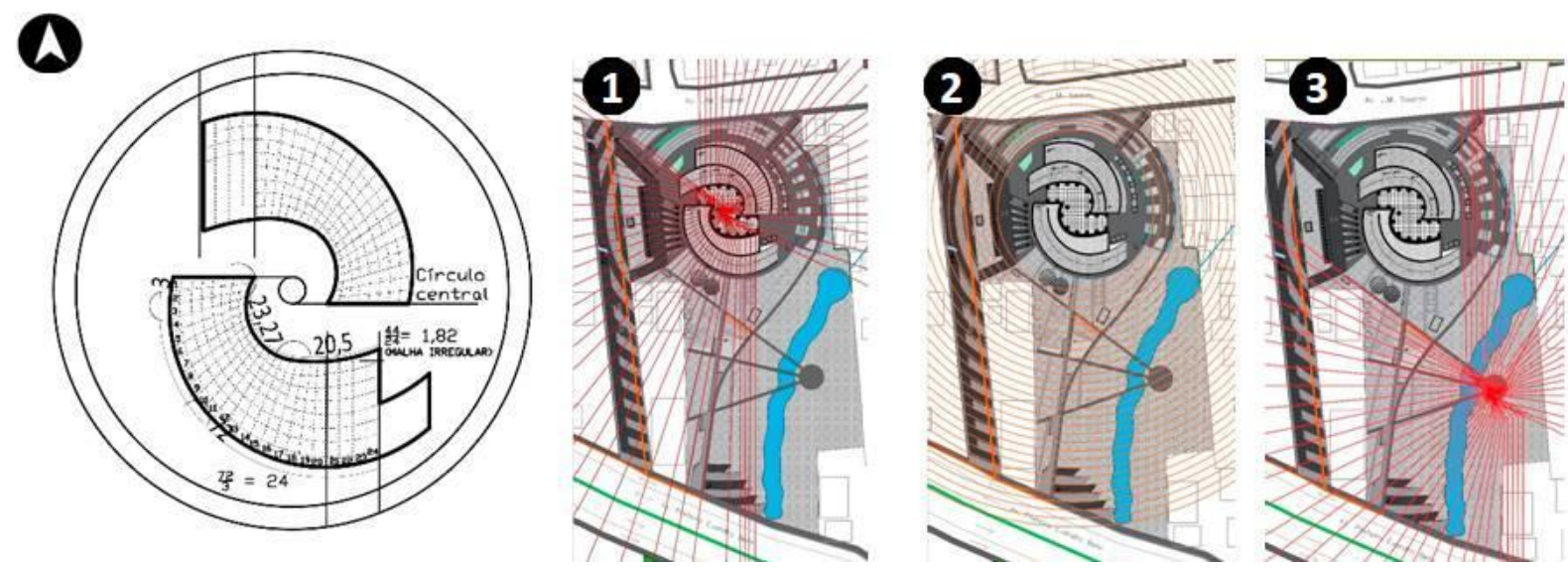

Fonte: Elaborado pelas autoras (2019). 
Figura 7: Implantação técnica e humanizada respectivamente.

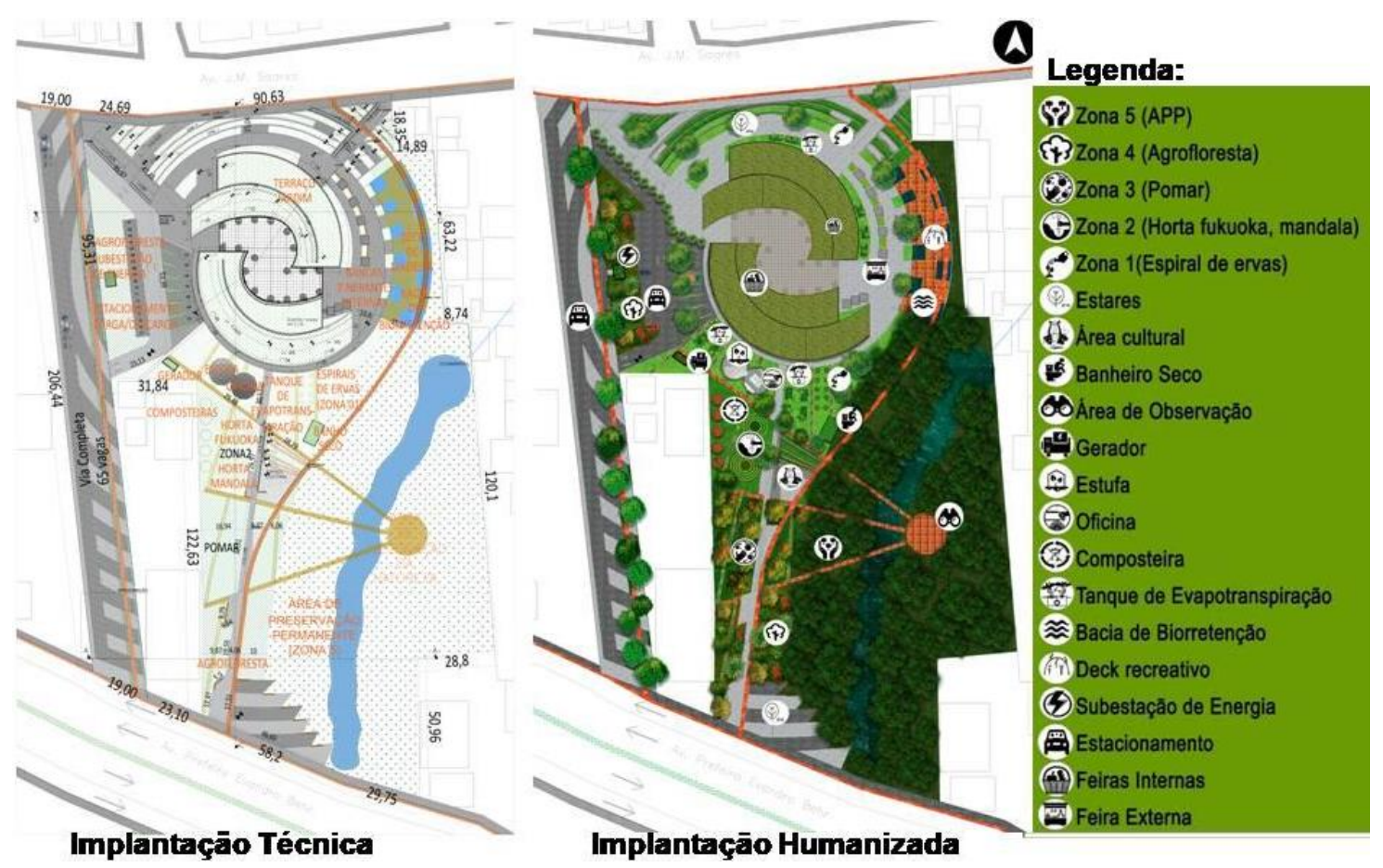

Fonte: Elaborado pelas autoras (2019).

Figura 8: Esquema de fluxos da proposição.

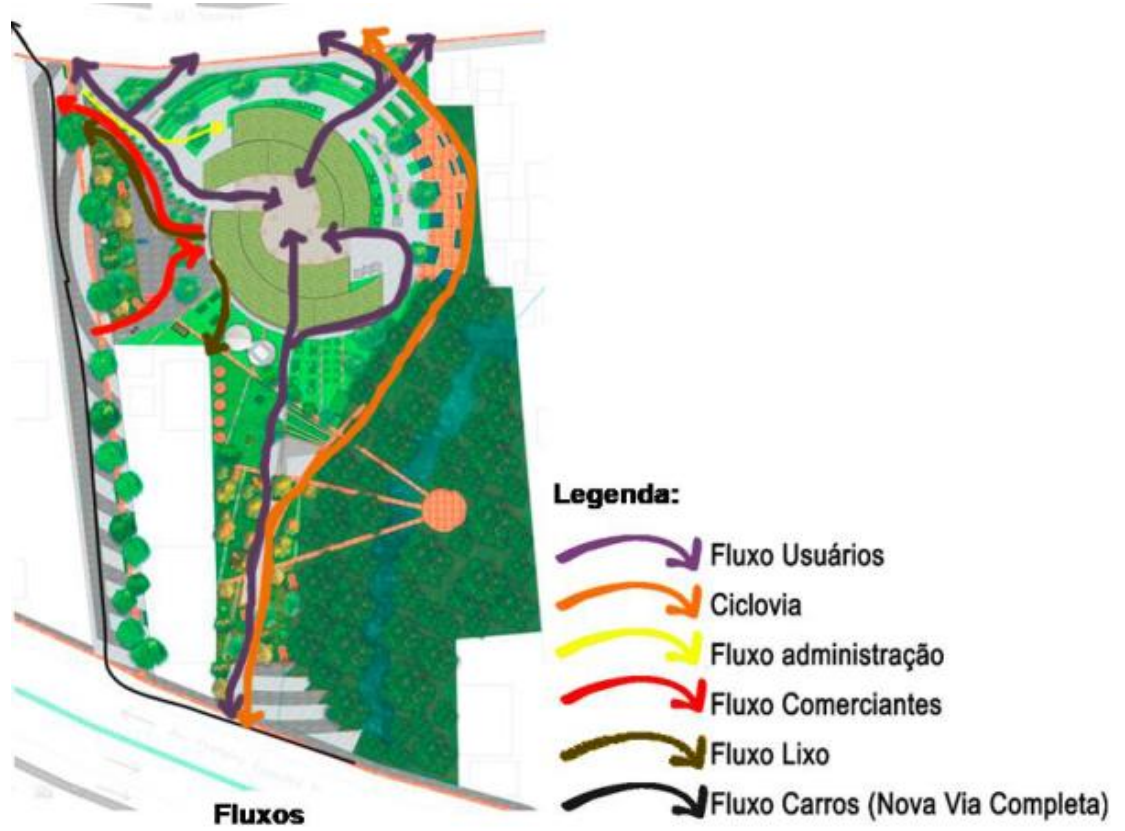

Fonte: Elaborado pelas autoras (2019).

\section{As zonas da permacultura}

O paisagismo produtivo foi definido de maneira sintrópica, através da análise do conceito das zonas da permacultura (Figura 9). De acordo com a proximidade da zona 0 (a edificação) e a área de preservação (zona 5), distribuídas conforme cada zona, atividade e as suas necessidades de manejo e acesso. A delimitação das zonas também foi feita de maneira consonante com o paisagismo para que o mesmo possa ser utilizado para fins culinários ou medicinais. 
Figura 9: Esquema de zoneamento de permacultura: todas as zonas, zona 5 e zona 4 respectivamente.
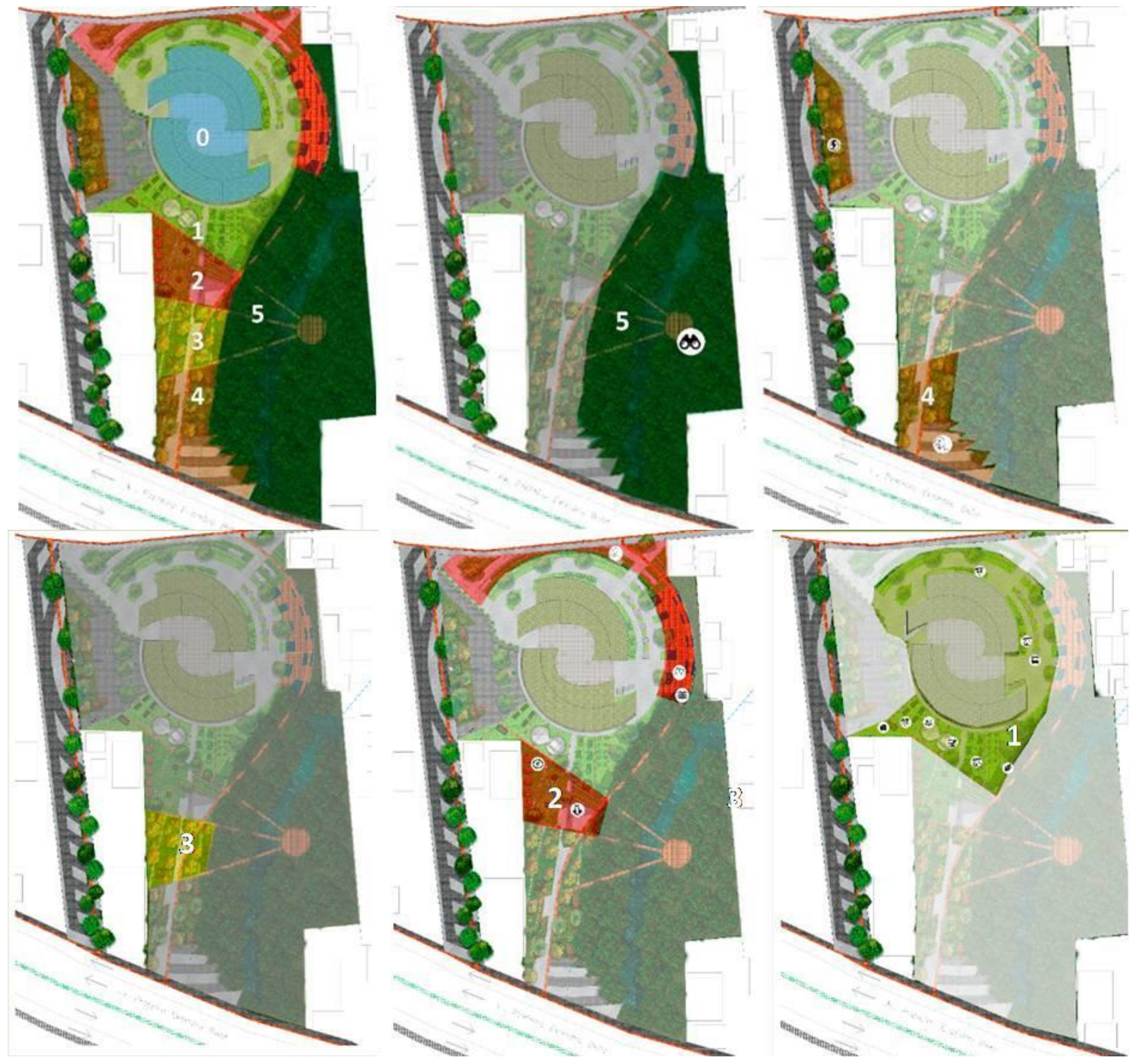

Fonte: Elaborado pelas autoras (2019).

A zona 5 é a zona de preservação, com espaço para observação da natureza e seus padrões. Nela foi proposta a localização de um espaço pequeno para estar e práticas individuais de yoga ou meditação.

A zona 4 (Figura 10) está próxima a via existente de maior fluxo (RS-509), e é uma área de transição que contém espaços de estar, áreas de agroflorestas que é e um sistema de plantio de alimentos em consórcio com a floresta. Este paisagismo possui árvores frutíferas nativas como laranjeiras, bergamoteiras, bananeiras, árvores de madeira de lei como o eucalipto e ainda hortaliças. Esta zona também está presente no setor oeste do lote, onde está implantada a subestação de energia.

A zona 3 (Figura 10) é a zona em que está localizado o pomar, onde estão distribuídas espécies nativas frutíferas como abacateiros, araçazeiros, butiazeiros, jabuticabeiras entre outras.

A zona 2 (Figura 11) contempla o paisagismo do acesso norte da edificação, ao sul do edifício estão as hortas em forma de mandalas. Para estas, foi projetado um paisagismo com introdução de hortaliças que demandam acesso e manejo mais frequentes, como abóboras, batata-doce, beterrabas entre outras. Nesta zona também está a área cultural, que foi idealizada através da criação de pequenos platôs que servem como arquibancada. Para este espaço, há a possibilidade de apresentações musicais, culturais bem como oficinas e palestras ao ar livre. Também compõem esta zona as infraestruturas de composteiras e bacia de biorretenção de águas pluviais, em que há um deque de madeira sobreposto que serve como espaço de lazer e estar. 
Figura 10: Diferentes perspectivas das zonas 4 e 3 respectivamente.
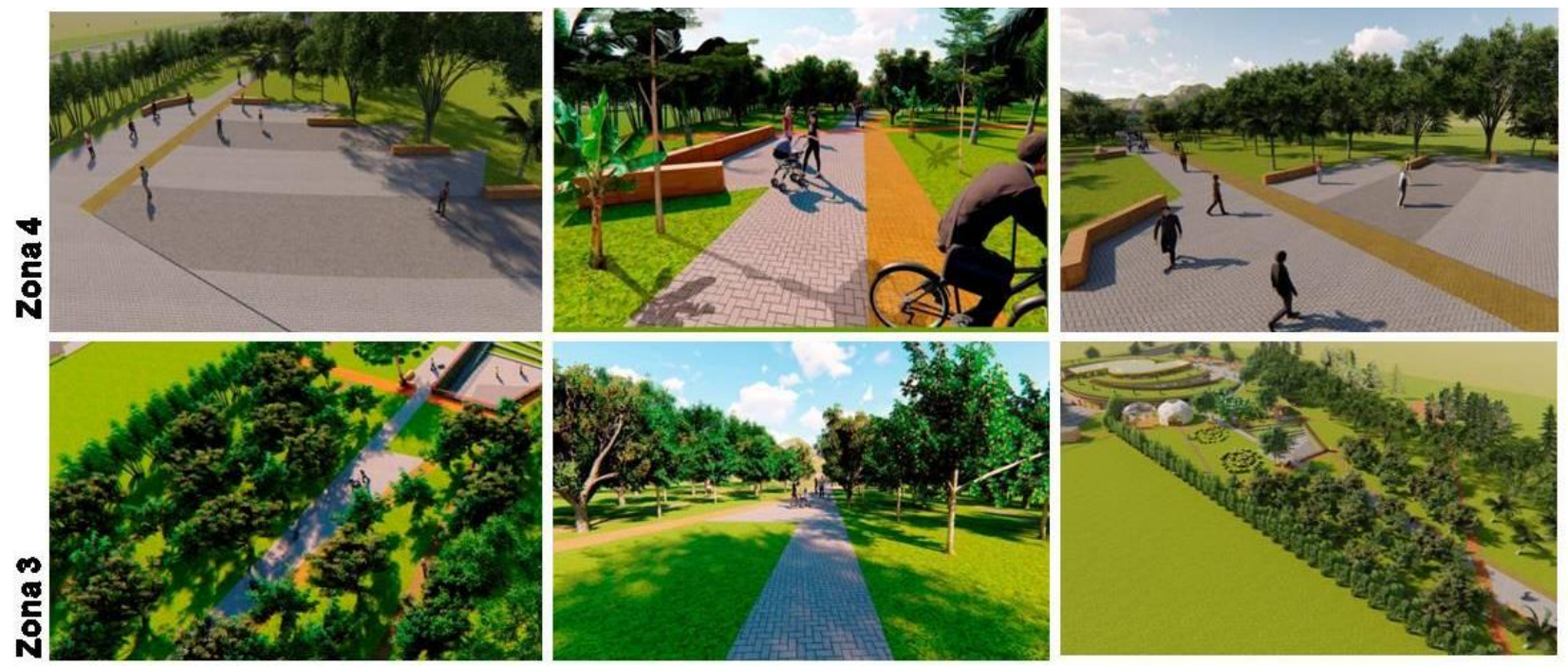

Fonte: Elaborado pelas autoras (2019).

Figura 11: Zona dois e seus elementos compositivos.
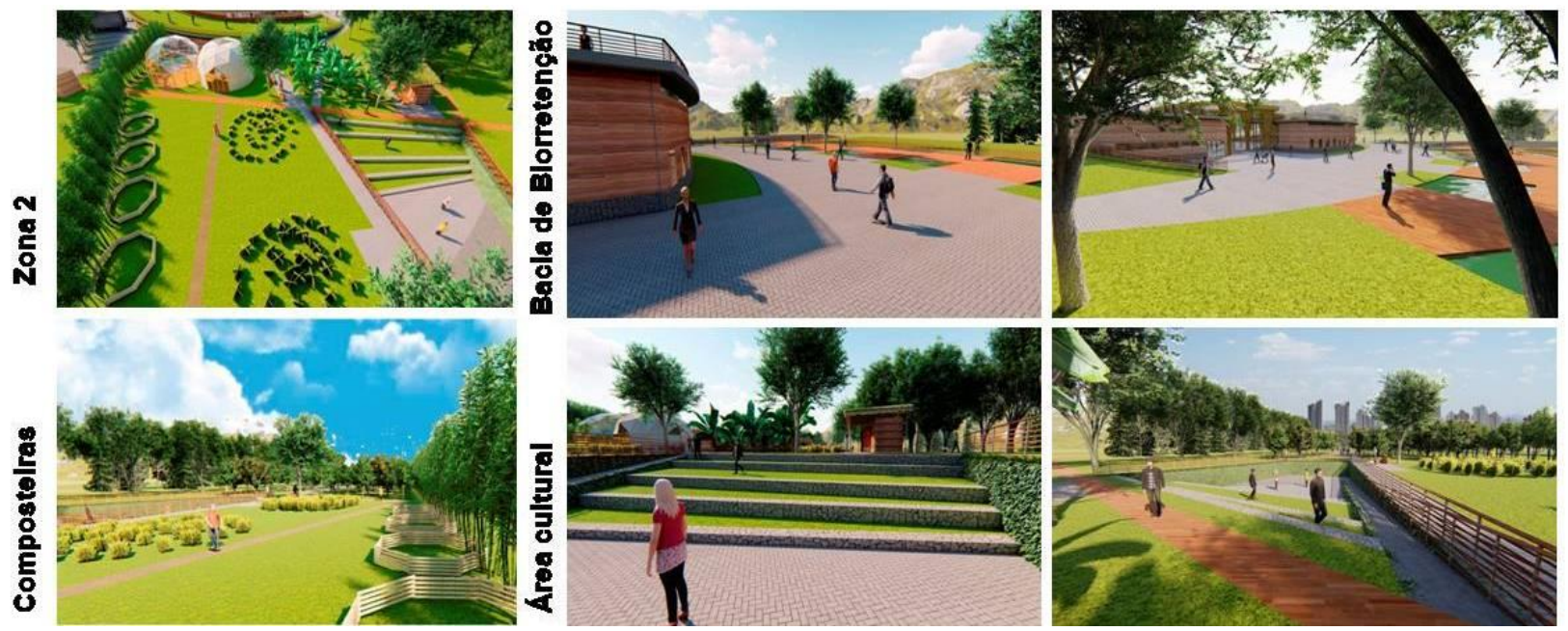

Fonte: Elaborado pelas autoras (2019).

A zona 1 (Figura 12) é a mais próxima à edificação e possui em seu paisagismo espirais de ervas, consórcio de hortaliças, condimentares e leguminosas, como tempero verde, cebolinha, manjericão, tomates entre outros. Nesta zona estão locadas duas estruturas geodésicas conjugadas: a estufa revestida com vidro e a oficina com placas ecológicas recicladas de caixa de leite. Ambas também podem ser utilizadas como oficinas práticas e área de manutenção das espécies vegetais implantadas no paisagismo. Há nesta zona também uma área de feiras externas (projetadas em estrutura de bambu) e baterias de banheiro seco, situado próximo à área cultural. Estes sanitários tem estrutura em bambu e paredes de terra compacta, neles, os dejetos são compostados e utilizados como adubo no local. Ainda nesta zona, estão instalados os sistemas de tratamento dos efluentes locais. Os tanques de evapotranspiração são sistemas que realizam o tratamento de águas cinzas e negras através de bactérias anaeróbicas, e de plantas com grande capacidade de evapotranspiração como as bananeiras e mamoeiros. 
Figura 12: Zona 1 e seus elementos compositivos.
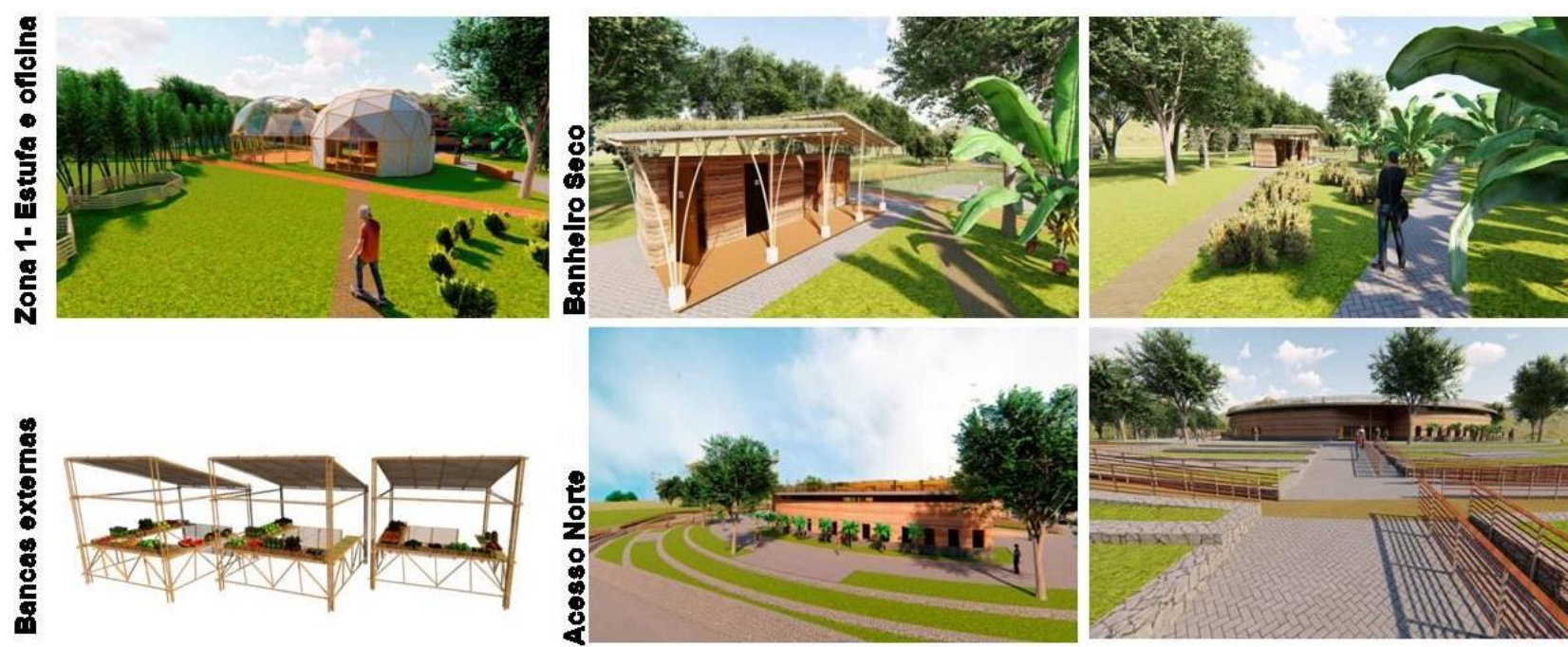

Fonte: Elaborado pelas autoras (2019).

\section{O projeto arquitetônico do Mercado Público (Zona 0) - Evolução Formal}

A evolução formal da edificação (Figura 13) se deu a partir do conceito com estudos de composição de retângulos áureos. Idealizando uma forma fluída e trazendo a questão do paisagismo produtivo, pensou-se na volumetria brotando da terra e que representa os vegetais. Assim, formou-se um jogo de volumes com grandes rampas que possibilitam o acesso do usuário a cobertura através de rampas.

Figura 13: Estudo e evolução da composição volumétrica do arquitetônico da proposta e inserção da volumetria no lote.

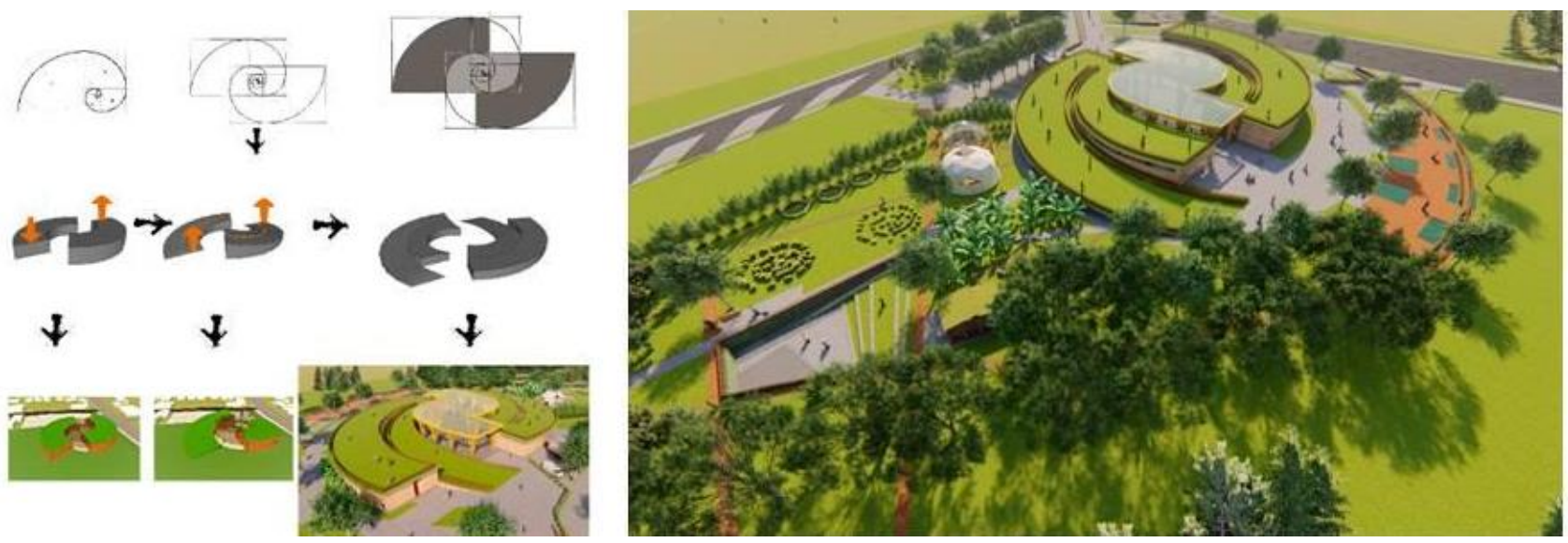

Fonte: Elaborado pelas autoras (2019).

A figura 14 representa a distribuição dos ambientes na edificação, seguida da planta baixa humanizada e planta técnica. Em relação à administração (amarelo), foi pensado em um sistema de cooperativas, então estão distribuídas as salas dos núcleos compositivos (permacultura, cultural e de comerciantes) e as salas de apoio necessárias como copa, estar e sanitários. Dentre estas, as salas de maior permanência foram voltadas ao norte para maior ventilação e iluminação natural. A zona comercial (vermelho) está distribuída nos dois volumes de maneira centralizada. $O$ acesso de comerciantes se dá pelo oeste da edificação, junto aos acessos de serviço. O setor de infraestrutura (azul) possui vestiário para os comerciantes, depósitos, salas de separação de resíduos, reciclagem, reservatório inferior e também sanitários para os usuários. O setor cultural (roxo) interno está mais ao sul e interliga o paisagismo com o setor cultural externo a leste. 
Figura 14: Fluxos e zonas, planta baixa humanizada e planta baixa técnica respectivamente.

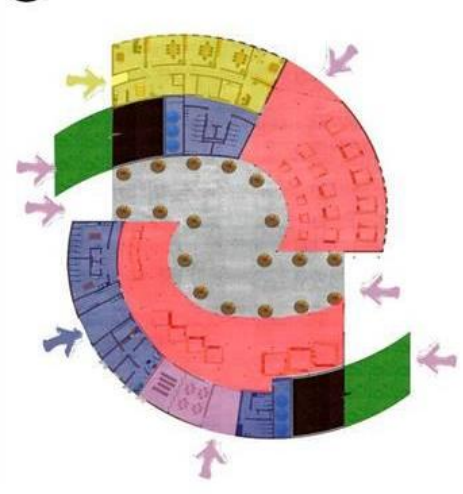

ACESSO COMERCIANTES ACESSO USUÁRIOS ACESSO ADMINISTRATIVO

ZONA COMERCIAL ZONA ADMINISTRAÇÃO ZONA INFRAESTRUTURA ZONA CULTURAL
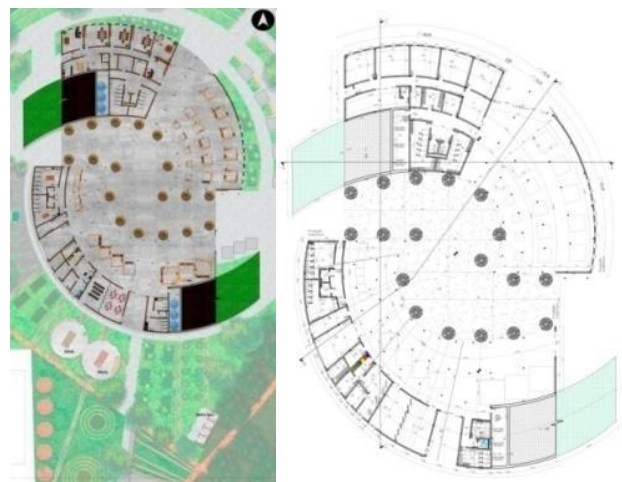

๑

Fonte: Elaborado pelas autoras (2019).

A estrutura de sustentação da edificação (Figura 15) foi proposta seguindo a sua malha radial, traçada a partir da centralidade das volumetrias. A estrutura é composta por vigas e pilares metálicos e com paredes de vedação em terra compactada, com a técnica de taipa de pilão (técnica gerada por meio de deposição e compressão da terra). A vedação horizontal de superior é de laje steel deck com cobertura verde. O elemento central é feita com vigas e estrutura de pilares de bambu, que tem volumetria inspirada no padrão dos troncos das árvores. A cobertura central é feita com módulos fotovoltaicos semitransparentes, servindo para a geração de energia no local (Figura 16). As laterais das rampas e as fundações das paredes são feitas com gabião de pedras.

A partir das premissas da permacultura, assim como da investigação e utilização de materiais locais, optouse pela utilização de eucalipto para as estruturas de vedação e para as bancas das feiras internas (Figura 16). Como trata-se de uma espécie exótica presente em grande quantidade no terreno, o emprego deste material foi definido visando um menor impacto sobre o meio ambiente, por serem alternativos e naturais.

Figura 15: Perspectiva explodida da estrutura da composição e materiais utilizados.

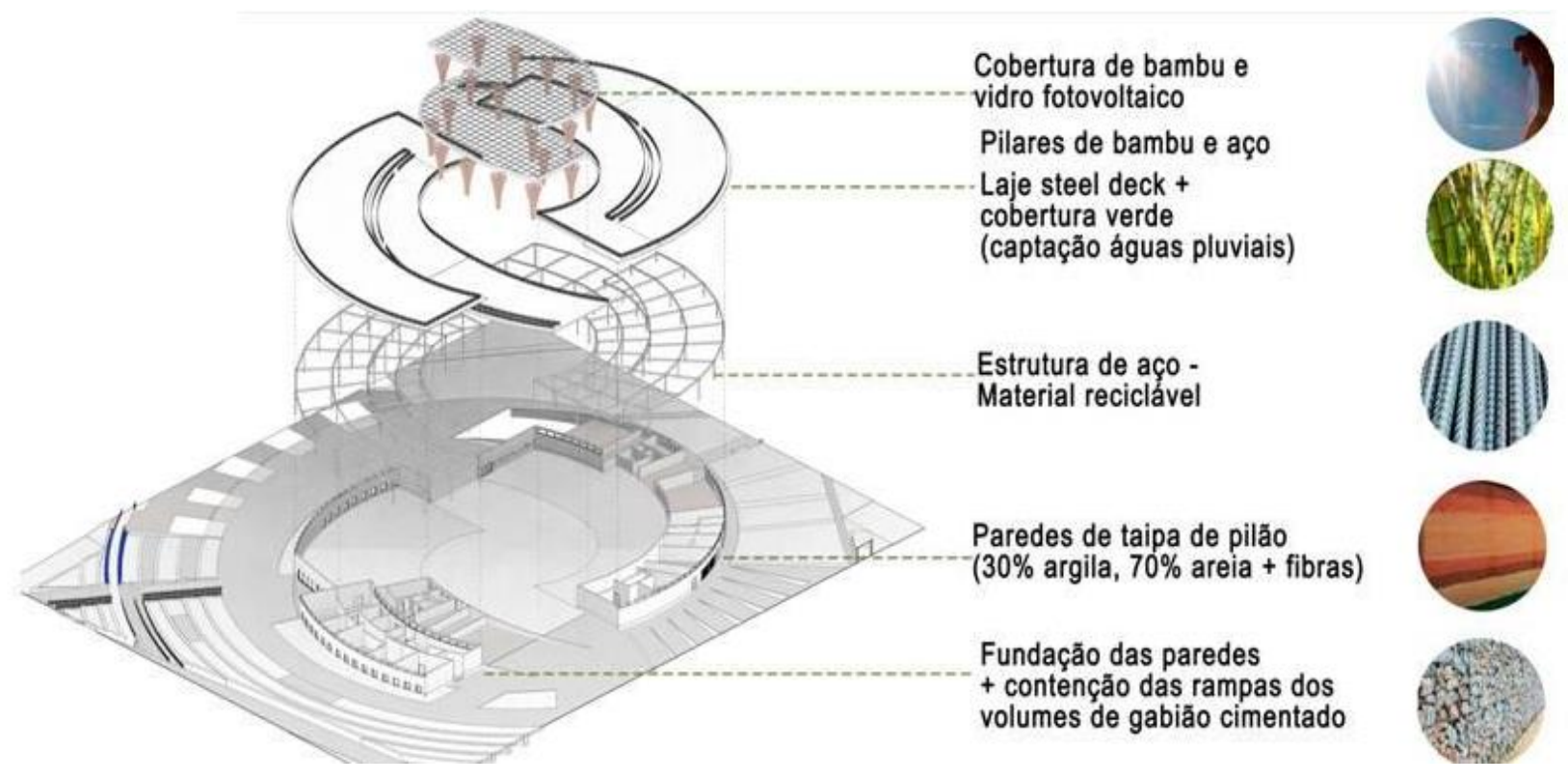

Fonte: Elaborado pelas autoras (2019). 
Figura 16: Mobiliário interno realizado com madeira local e estrutura de bambu na volumetria central.
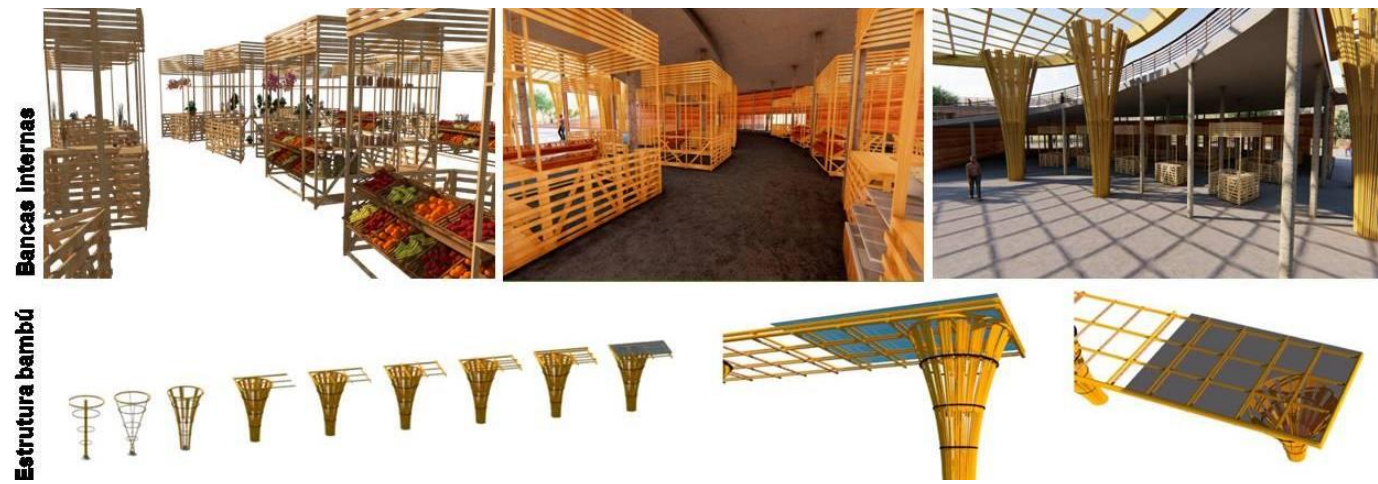

Fonte: Elaborado pelas autoras (2019).

Considerando o uso da arquitetura bioclimática, distribuíram-se as aberturas das fenestrações de maneira que a edificação obtivesse insolação e ventilação de forma que contribuíssem com o conforto térmico e lumínico (Figura 17). Estes aspectos favorecem para que seja necessário um mínimo de utilização de condicionadores de ar e iluminação artificial.O corte de pele (Figura 18) identifica o funcionamento da estrutura da edificação, com as paredes em taipa de pilão, a cobertura verde, a fundação das paredes e da estrutura de vigas e pilares.

Figura 17: Esquema identificando a ventilação cruzada na edificação.
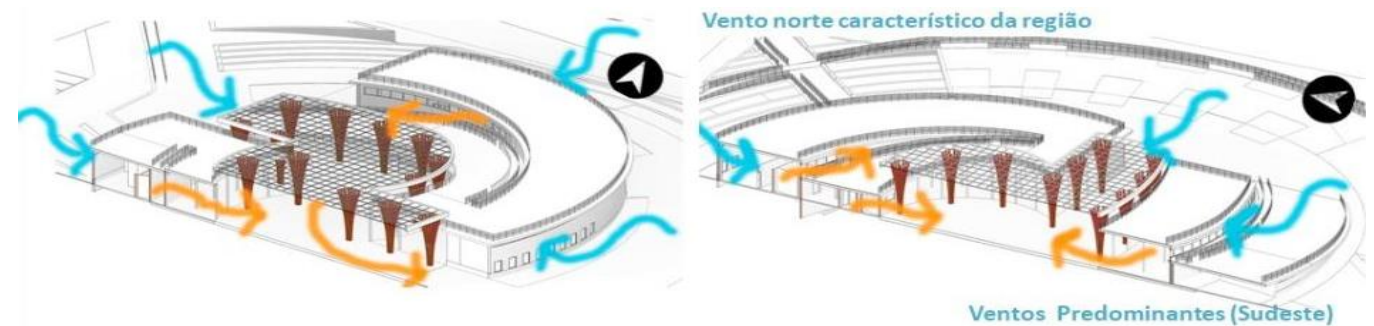

Fonte: Elaborado pelas autoras (2019).

Figura 18: Corte de pele da edificação proposta.

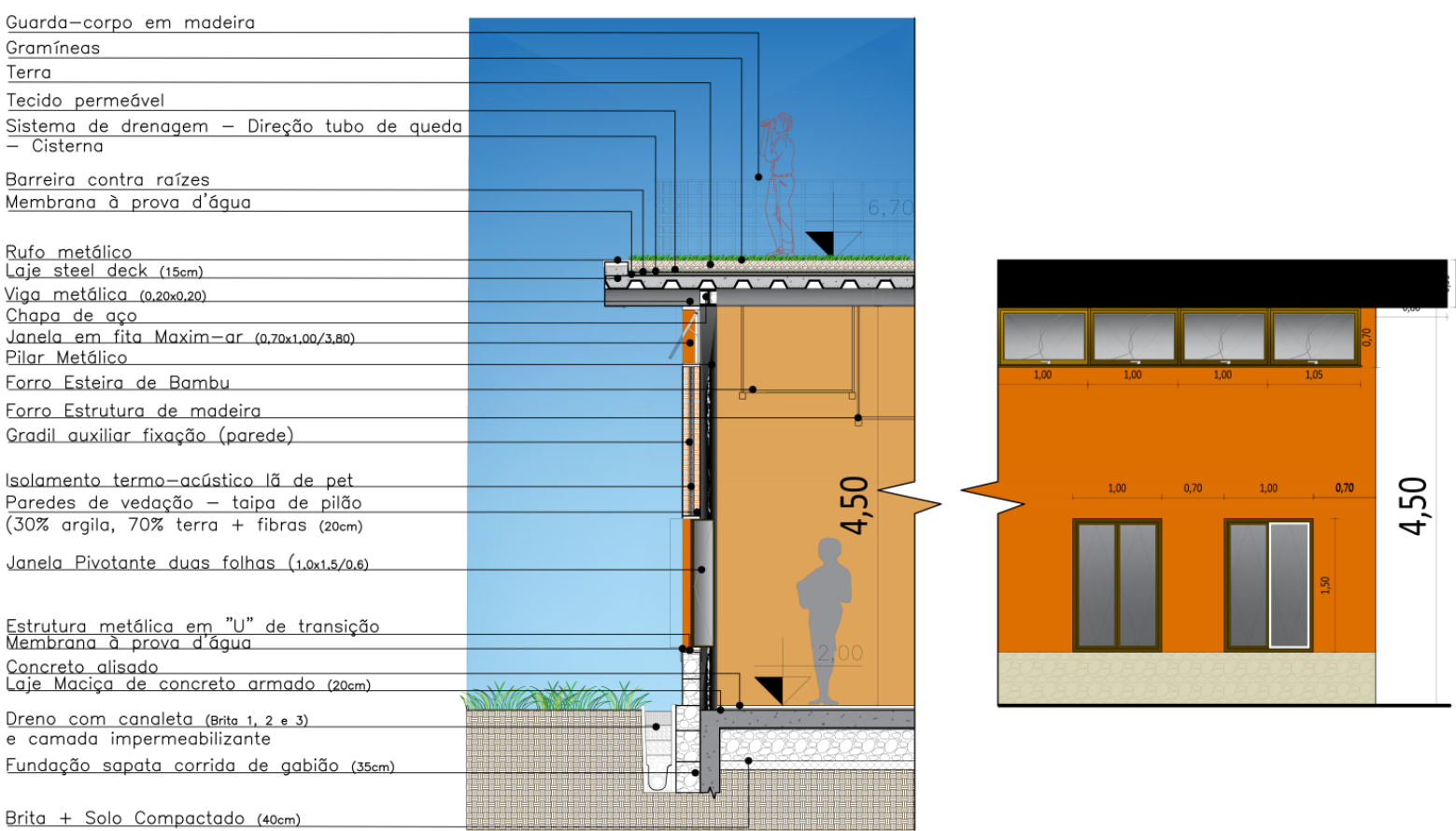

Fonte: Elaborado pelas autoras (2019). 
Assim, observa-se o detalhamento dos resultados obtidos como anteprojeto do Mercado Público e seu paisagismo através da permacultura. Os mesmos foram possíveis através da análise do estado da arte desta tipologia de edificação e também dos aspectos abordados pelos conceitos e design da permacultura, utilizados em todas as etapas do processo de projeto.

\section{CONCLUSÃO}

Os Mercados Públicos surgiram como forma de intercâmbio de produtos e foram também modificadores do espaço e fontes de desenvolvimento de povoados e vilas. Esta tipologia arquitetônica se consolidou no decorrer do tempo e resiste até os dias atuais como um espaço econômico, político e social dentro de centros urbanos. Eles são acessíveis para diferentes públicos, representam espaços democráticos e articuladores dentro de uma cidade. É um local onde acontecem diversas formas de interações socioculturais de uma sociedade, sendo assim um potencializador de coletividade e urbanidade, e contribuidores para a sociedade atual, alinhados com as teorias da permacultura.

Através da análise da situação do Bairro Camobi, foi identificado o sítio de trabalho e inserido o conceito de Permacultura em todas as fases do projeto. Assim, foi possível projetar um espaço com tecnologias e materiais alternativos de construção para propiciar a comercialização de produtos de forma adequada, sustentável e resiliente. Além disso, o local fornece um espaço cultural, de ensino, lazer e estar, que valoriza os pedestres e a mobilidade na região. A permacultura teve presença fundamental como conceito norteador, propiciando indicação de formas compositivas, relações urbanísticas e também de materiais. Desse modo, foi realizada uma proposta que busca a sustentabilidade e almeja recuperar vazios urbanos degradados e recuperar os biomas locais.

Por fim, a proposta resultou em um objeto arquitetônico que visa a valorização da sociedade e da natureza, aproximando-as e promovendo troca de valores urbanos e socioculturais. Este espaço configura-se como um catalisador para tais intenções através dos conceitos e princípios da permacultura. O projeto apresenta uma possibilidade de inserção na cidade, respeitando a análise de seu entorno, dos condicionantes naturais e sociais através da história. Estas premissas aparecem refletidas tanto no processo de projeto como no resultado arquitetônico, com formas e materialidades aliadas à permacultura.

\section{REFERÊNCIAS}

BARBosA, M. Reinventar Espaço Urbano, Mercado Público do Benfica. Trabalho Final de Graduação, Faculdade de Arquitetura e Urbanismo, Universidade de Fortaleza, Fortaleza, 2016. Disponível em https://issuu.com/morgannabatista/docs/caderno final issuu r01. Acessado em 27/04/2019.

CJ, C. Conceitos da Permacultura, 2016. Disponível em https://ipoema.org.br/2016/12/12/conceitos-da-permacultura/. Acessado em 27/04/2019.

DIAS, B. Permacultura: As suas zonas $e$ as suas funções, 2019. Disponível em https://open4sustainability.pt/permacultura-as-zonas-as-suas-funcoes/. Acessado em 10/05/2019.

DIAS, G. Pegada ecológica e sustentabilidade Humana. São Paulo, 2007. Disponível em http://www.ifcursos.com.br/sistema/admin/arquivos/18-19-25-genebaldofreiredias-pegadaecologica painel\%3B\%3B.pdf. Acessado em 27/04/2019.

FERRER, J. O Número De Ouro Na Arte, Arquitetura E Natureza: Beleza E Harmonia, 2005. Universidade Católica de Brasília, Brasília, 2005.

HOLMGREN, D. Permacultura: Princípios e Caminhos Além da Sustentabilidade, Ed. Via Sapiens, 2013, Austrália, 2002. Disponível em https://biowit.files.wordpress.com/2010/11/livreto-permacultura-1.pdf. Acessado em 27/04/2019.

IBGE, 2019. Panorama de Santa Maria/RS. Disponível em https://cidades.ibge.gov.br/brasil/rs/santa-maria/panorama. Acessado em 20/08/2020.

MOLLISON, B. Introdução a Permacultura. Edição traduzida, PNFC (Projeto Novas Fronteiras da Cooperação para o Desenvolvimento Sustentável), Brasília, DF, 1998.

SANTA MARIA, 2019. Santa Maria em Dados. Disponível em http://santamariaemdados.com.br/1-aspectos-gerais/. Acessado em 13/05/2019.

NOTA DO EDITOR $\left(^{*}\right)$ : O conteúdo do artigo e as imagens nele publicadas são de responsabilidade do(s) autor(es). 